\title{
STUDI PENERJEMAHAN METAFORA DALAM NASKAH DRAMA DI UNIVERSITAS NASIONAL JAKARTA
}

\author{
Imelda Malawaty Simorangkir \\ Prodi Pendidikan Bahasa Inggris, FBS, Universitas Indraprasta PGRI \\ Pos-el: imelsimorangkir@gmail.com \\ Dewi Mutiara Indah Ayu \\ Prodi Pendidikan Bahasa Inggris, FBS, Universitas Indraprasta PGRI \\ Pos-el: dmiayu33@gmail.com
}

\begin{abstract}
ABSTRAK
Penelitian studi penerjemahan metafora pada naskah drama di Universitas Nasional Jakarta bertujuan untuk mengetahui terjemahan metafora pada naskah drama dan jenis-jenis terjemahan metafora. Pada dasarnya, menerjemahkan metafora bukanlah hal yang mudah, karena metafora merupakan bahasa kiasan yang menyatakan sesuatu perbandingan tidak sama yaitu mengacu pada dua makna baik secara ekplisit maupun implisit. Kalimat yang mengandung metafora yang ditemukan dalam naskah drama. Atas dasar alasan di atas itulah maka penelitian ini menarik untuk diangkat. Metode yang digunakan dalam penelitian ini adalah kualitatif deskriptif yang mengacu pada penelitian kelas (action research). Sehingga,hasil jenis-jenis metafora seperti metaphora Perbandingan dan Persamaan
\end{abstract}

Kata Kunci: studi penerjemahan, metafora, naskah drama, mahasiswa fakultas bahasa dan sastra

ABSTRACT

The purpose of the research study in metaphore in the English text literary at National University is to enlarge the knowlodge in the translation of metaphore and the types of metaphore categorize that have been found in English text literary especially in role plays. Since the research is begun, translating the metaphore text was not the easiest once. In fact, metaphore becomes the part of figurative language which is refers to two parts like Implicit and Expicit. Literary text has been used by the English students as their data because they found metaphore sentences to be analyze in their research. This research uses descriptive qualitative research that focus on observation during the class. Therefore, all the data were collected dan arranged in dictionary that would be useful for the students in faculty of letters.

Key Words : translation study, metaphore, literary texts, the students of faculty of letters

\section{PENDAHULUAN \\ Latar Belakang}

Seorang penerjemah harus dapat menjembatani antara makna yang terdapat pada Bahasa Sumber (BS) ke Bahasa Target (BT). Dalam kamus Oxford dijelaskan bahwa proses penerjemahan merupakan sebuah proses mengubah suatu naskah/teks baik itu yang tertulis maupun lisan ke dalam bahasa yang lain (Isadore,1977). Selanjutnya, Larson (1998:3) menjelaskan bahwa dalam suatu proses penerjemahan terdiri atas mempelajari unsur leksikal, 
struktur gramatikal, situasi komunikasi, dan konteks budaya dari teks BS, menganalisis suatu teks sendiri sangatlah penting untuk menentukan makna dan selanjutnya merekontruksinya dengan makna dan informasi yang sama dengan menggunakan leksikal, struktur gramatikal yang sesuai dengan BT dan juga konteks budaya yag terdapat didalamnya. Oleh sebab itu, proses penerjemahan meliputi unsur-unsur semantik, pragmatik, dan sintaksis. Jika seorang penerjemah berpegang teguh kepada pemahaman terhadap ketiga bidang linguistik tersebut, maka akan menghasilkan hasil terjemahan yang akurat (accurate), jelas (clear), dan alami (natural).

Dalam menjalani suatu proses penerjemahan, seorang penerjemah harus mampu melaksanakan prinsip-prinsip tersebut untuk mendapatkan hasil terjemahan yang terbaik. Roger (1993:6) menyampaikan bahwa terdapat 3 prinsip yang harus dilakukan untuk mendapatkan terjemahan yang terbaik. Pertama, dengan menggunakan bentukbahasa bakudari BT. Kedua, mengomunikasikan sebanyak mungkin dengan pemakai dari hasil terjemahan tersebut sehingga makna kata yang ada bisa dimengerti oleh pemakai dari BT. Ketiga, menjaga dinamika makna dari BS. Hal ini dimaksudkan bahwa terjemahan ditampilkan sedemikian rupa sehingga hasilnya menyerupai tampilan seperti dalam BS. Dari ketiga hal tersebut, dapat disimpulkan bahwa hasil terjemahan bisa dinilai dari tiga aspek yaitu: keakuratan (accuracy), kejelasan (clarity)dan kealamian (naturalness) makna dari terjemahan tersebut. Lawrence (1991, 200--205) dalam jurnalnya yang berjudul Translation Naturalness in Literary Works: English to Persianyang dipublikasikan di Journal of English and Literature.Selanjutnya dia juga menyebutkan terdapat 5 kondisi yang berhubungan dengan tingkat kealamian darisebuah terjemahan yaitu:(1) terjemahan yang alami atau natural seharusnya tidakterjemahan yang literal (Belloc, 1931); (2) pembaca hasil terjemahan itu tidak akan menyadari kalau itu adalah sebuah hasil terjemahan (Rahimi, 2004); (3) penerjemah bebas menambahkan kata-kata dalam BT kalau itu diperlukan(Tytler, 1997); (4) penerjemah bisa memahami pembaca dari BT saat si penulis tersebutmembuat teks terebut (Nida, 1969) dan(5) penerjemah yang natural memakai terjemahan yang komunikatif daripada terjemahan semantik (Newmark, 1981).

Penelitian ini menganalisishasil terjemahan metafora pada Mahasiswa Jurusan Sastra Inggris, Fakultas Bahasa dan Sastra, Universitas Nasional Jakarta dari segi penerjemahannya dan juga kualitas terjemahannya yang bersifat deskriptif kualitatif. Metafora bertumpu pada konsep perbandingan juga pengalihan baik yang secara eksplisit maupun implisit. Metafora memiliki ciri menyampaikan sesuatu secara tidak langsung atau adanya ketidaksesuaian antara apa yang disampaikan dengan apa yang dimaksud. Oleh sebab itu, akan dipaprkan beberapa hal yang berkenaan dengan teori dan masalah penerjemahan. Data berupa teks novel terjemahan dalam bahasa Inggris. Akan tetapi, sebelum dianalisis, data tersebut terlebih dahulu telah diterjemahkan oleh para rekan dosen paralel yang mengajar mata kuliah translation di kampus Universitas Nasional, Jakarta ke dalam bahasa Inggris. Hasil terjemahan tersebut digunakan sebagai data analisis walaupun dalam proses penerjemahan, para mahasiswa diizinkan menggunakan kamus. Analisis terhadap hasil terjemahan tersebut dilakukan dengan cara membandingkan hasil terjemahan mahasiswa dengan hasil terjemahan yang dikerjakan oleh para rekan dosen paralel yang mengampu mata kuliah terjemahan (model terjemahan). Setelah data diperoleh dengan lengkap, data dianalisis sesuai dengan kriteria yang telah ditentukan, yaitu tingkat keberterimaan hasil terjemahan mereka yang berhubungan dengan keakuratan hasil terjemahan. Tatkala sebuah hasil terjemahan akurat, makna yang disampaikan akan jelas. Selanjutnya pilihan kata yang dipilih tersebut alami seperti yang dipakai dalam bahasa target (BT). Dengan memperhatikan pandangan Newmark (1981:293) bahwa metafora tidak selalu dapat diterjemahkan secara harfiah atau kata demi kata, dan konsep kesepadanan dinamis yang 
dikemukakan oleh Danesi (2004: 12) peneliti bermaksud melakukan studi atas terjemahan metafora dari bahasa Inggris ke dalam Indonesia dengan data yang berasal dari novel berbahasa Inggris dan terjemahannya dalam bahasa Indonesia.

\section{Rumusan Masalah}

Berdasarkan latar belakang masalah yang telah dipaparkan di atas, rumusan masalah penelitian ini adalah sebagai berikut.

1. Bagaimanakah studi penerjemahan metafora pada teks karya sastra?

2. Kesulitan apa saja yang dihadapi oleh mahasiswa dalam menerjemahkan teks metafora berdasarkan karya sastra?

3. Bagaimana cara agar hasil terjemahan metafora yang dianalisis oleh mahasiswa mencapai titik kewajaran serta akurat?

\section{Tujuan Penelitian}

Adapun tujuan penelitian ini adalah sebagai berikut.

1. Untuk memahami studi penerjemahan metafora pada karya sastra.

2. Untuk mengetahui tiap kesulitan yang dihadapi oleh mahasiswa dalam menerjemahkan teks metafora berdasarkan karya sastra.

3. Untuk mengetahui langkah apa saja yang harus ditempuh agar hasil terjemahan metafora yang dianalisis oleh mahasiswa mencapai titik kewajaran serta akurat.

\section{Tinjauan Pustaka}

\section{Pengertian Metafora}

Secara etimologi, terminologi metafora terbentuk melalui perpaduan dua kata Yunani 'meta' (di atas) dan 'pherein' (mengalihkan atau memindahkan). Dalam bahasa Yunani modern, kata metafora juga bermakna 'trasfer' atau 'transfor'. Dengan demikian, metafora adalah pengalihan citra, makna, atau kualitas sebuah ungkapan kepada suata ungkapan lain (Classe, 2000:941). Pengalihan tersebut dilakukan dengan cara merujuk suatu konsep kepada konsep lain untuk mengisyaratkan kesamaan, analogi atau hubungan kedua konsep tersebut. Sebagai contoh dalam metafora "Pelanggan adalah raja," berbagai citra atau kualitas seorang raja, seperti kekuasaan, pengaruh, posisi, dan sebagainya dipindahkan kepada pelanggan. Ungkapan Shakespeare yang sangat terkenal "All the world's a stage" adalah metafora yang sering dikutip. Metafora ini mengindikasikan bahwa "the world" dan "stage" adalah dua hal yang analog. Berikut adalah uraian singkat tentang keempat teori tersebut, yang secara khusus ditinjau dari perspektif penerjemahan.

\section{Komponen Metafora}

Berdasarkan paparan di atas, terungkap bahwa struktur sebuah metafora dibagi ke dalam tiga komponen:

(1) konsep atau hal yang dibicarakan agar lebih dipahami (topik atau vehicle);

(2) konsep yang dapat dipahami (citra atau tenor); dan

(3) makna atau kualitas yang memperlihatkan persamaan antara citra dan topik (ground atau "titik kesamaan"). Dengan demikian dalam contoh "Guru adalah matahari bangsa" di atas, "Guru" merupakan "topik", "matahari" merupakan "citra", dan "menerangi" dan "menghangatkan" merupakan "titik kesamaan" 
Ketiga pembangun komponen metafora tidak selalu disebutkan secara eksplisit. Adakalanya, salah satu ketiga bagian itu (topik, sebagian dari citra, atau titik kemiripan) dinyatakan secara implisit. Sehubungan dengan itu Orrechioni (dalam Zaimar, 2002: 48--49) membedakan metafora in absentia, yang bersifat implisit. Dalam metafora "Tono adalah buaya darat", misalnya, kedua unsur yang dibandingkan muncul_-"Tono" sebagai vehicle" dan "buaya darat" sebagai tenor). Sedangkan dalam metafora "Banyak yang ingin mempersunting mawar bunga desa itu. Kata mawar dibandingkan secara in absentia dengan gadis. Dalam konteks ini, "mawar" sebagai citra muncul, sedangkan "gadis" sebagai topik tidak mucul. Dengan demikian, terjadi perbandingan implisit. Untuk mengetahui titik kemiripan dalam metafora seperti ini, diperlukan pengetahuan tentang konteks tempat metafora itu digunakan, pemahaman terhadap makna "mawar" dalam masyarakat penutur, dan unsur implisit lainnya.

\section{Prosedur Mengindentifikasi Metafora}

Pemahaman atas definisi, komponen, dan tipe metafora belum menjamin kemampuan mengidentifikasi keberadaan majas ini dalam wacana, apalagi bila wacana yang dianalisa merupakan korpus besar. Kenmayr (2011: 15--16) menegaskan bahwa pendekatan "i-know-itwhen-i-see-it" atau intuitif tidak bisa diharapkan untuk menghasilkan identifikasi metafora yang akurat. Olek karena itu, dibutuhkan prosedur yang terukur. Untuk menjawab kebutuhan ini, kelompok Pragglejaz menyusun Metaphore Identification Procedure (MIP), yang dirancang secara khusus bagi para peneliti untuk mengenali metafora dalam bahasa lisan maupun tulisan. Prosedur ini bertujuan untuk menentukan apakah unit leksikal tertentu dalam wacana berperan sebagai metafora dengan melihat hubungan unit leksikal tersebut dalam wacana. Karena banyak kata yang berfungsi sebagai metafora dalam konteks yang berbeda. Pragglejaz (2007) merumuskan MIP sebagai berikut.

1. Baca wacana secara menyeluruh untuk membangun pemahaman umum tentang maknanya.

2. Tentukan unit leksikal dalam wacana.

3. a. Untuk setiap unit leksikal dalam teks, lihat maknanya dalam konteks, yaitu, bagaimana makna itu berlaku sebgai suatu entitas, relasi, atau atribut dalamsituasi yang ditimbulkan oleh teks (makna kontekstual). Perhitungkan apa yang datang sebelum dan sesudah unit leksikal.

b.Untuk setiap unit leksikal, tentukan apakah unit tersebut memiliki makna kontemporer yang lebih mendasar dalam konteks lain daripada dalam kontekstersebut. Dalam identifikasi metafora ini, makna dasar cenderung: (i) lebih nyata (apa yang diungkapkan lebih mudah dibayangkan, dilihat, didengar,diraba, dicium, dan dirasakan); (ii) terikat dengan tindakan fisik; (iii) lebih tepat(tidak samar-samar); dan (iv) secara historis lebih tua. Makna dasar harus merupakan makna yang paling sering muncul dari unit leksikal tersebut.

c. Jika unit leksikal memiliki makna kontemporer yang lebih mendasarkonteks lain dibandingkan dengan konteks yang ada, periksa apakah makna kontekstual berbeda dengan makna dasar tetapi dapat dimengerti melalui perbandingan dengn makna dasar tersebut.

4. Jika iya, tandai unit leksikal itu sebagai metafora.

\section{Prosedur Penerjemahan}


Roger T. Bell (1993:5) mengatakan,"translation is the expression in oanother language (or target language) of what has been expressed in another, source language, preserving semantic and stylistic equivalences". Yang maksudnya, bahwa terjemahan adalah ekspresi dari bahasa sumber dari apa yang diekspresikan dari bahasa sasaran dengan mempertahankan padanan semantik dan stylistiknya.

Dalam Prosedur penerjemahan adalah teknik atau cara yang dipakai penerjemah selama proses penerjemahan berlangsung pada tataran kata, frasa, dan kalimat. Metode penerjemahanmerupakan prinsip yang mendasari cara kita dalam menerjemahkan teks yang bermuara pada bentuk terjemahannya. Metode penerjemahan dipakai agar kegiatan penerjemahan yang dilakukan dapat lebih efektif dan efisien.

Vinay dan Darbenet dalam Munday (2001: 56--58) membagi penerjemahan menjadi dua yakni penerjemahan langsung dan tidak langsung (direct translation dan oblique translation).

\section{Metode Penerjemahan}

Newmark menyebutkan ada delapan jenis metode penerjemahan yang dibagi menjadi dua golongan, yaitu berorientasi pada bahasa sumber (BSu) dan berorientasi pada bahasa sasaran (BSa): Metode penerjemahan ini juga dikenal dengan Diagram V.

\section{a. Berorientasi pada BSu}

1). Penerjemahan kata demi kata: dilakukan dengan menerjemahkan kata demi kata dan membiarkan susunan kalimat seperti dalam sumber.

2) Penerjemahan harfiah: dilakukan dengan mengubah struktur kalimat namun kata dangaya bahasa masih dipertahankan.

3) Penerjemahan setia: dilakukan dengan mempertahankan sejauh mungkin aspek format atau aspek bentuk sehingga dapat secara lengkap melihat segi bentuknya.

4) Penerjemahan semantis: menekankan pada penggunaan istilah, kata kunci, atau ungkapan yang harus dihadirkan dalam hasil terjemahan.

\section{b. Berorientasi pada BSa}

1) Adaptasi (saduran): menekankan pada isi pesan sedang bentuk disesuaikan dengan kebutuhan pembaca.

2) Penerjemahan bebas: menekankan pada pengalihan pesan sedang pengungkapannya dilakukan sesuai kebutuhan calon pembaca.

3) Penerjemahan idiomatis: berusaha menemukan padanan istilah, ungkapan, dan idiom yang tersedia dalam bahasa sasaran.

4)Penerjemahan komunikatif: menekankan pada pesan dan memperhatikan prinsipprinsipkomunikasi, namun tidak menerjemahkan secara bebas.

Newmark (1981:45) telah mengelompokkan metode-metode penerjemahan berikut ke dalam dua kelompok besar. Empat metode pertama lebih ditekankan pada Bsu, yaitu Word-forword translation, Literal translation, Faithful translation, dan Semantic translation dan empat metode kedua lebih ditekankan pada Bsa, Adaptation, Free translation, Idiomatic translation, dan Communicative translation.

1. Penerjemahan Kata-demi-kata

Dalam metode penerjemahan kata-demi-kata (word-for-word translation), biasanya kata-kata Tsa langsung diletakkan di bawah versi Tsu atau disebut dengan interlinear translation. Metode penerjemahan ini sangat terikat pada tataran kata, sehingga susunan kata sangat dipertahankan. Dalam melakukan tugasnya, penerjemah hanya mencari padanan kata 
Bsu dalam Bsa. Susunan kata dalam kalimat terjemahan sama persis dengan susunan kata dalam kalimat Bsu. Setiap kata diterjemahkan satu-satu berdasarkan makna umum atau di luar konteks, sedangkan kata-kata yang berkaitan dengan budaya diterjemahkan secara harfiah. Umumnya metode ini digunakan pada tahapan prapenerjemahan pada saat penerjemah menerjemahkan teks yang sukar atau untuk memahami mekanisme Bsu. Jadi metode ini digunakan pada tahap analisis atau tahap awal pengalihan. Biasanya metode ini digunakan untuk penerjemahan tujuan khusus, namun tidak lazim digunakan untuk penerjemahan yang umum. Kecuali jika struktur kalimat bahasa Inggris sama dengan struktur kalimat bahasa Indonesia (lihat contoh nomor 3 dan 4 di bawah ini) (Catford, 1965:25; Soemarno, 1983:25; Newmark, 1981:45--46; Machali, 2000:50--51; Nababan, 2003:30).

2. Penerjemahan Harfiah

Penerjemahan harfiah (literal translation) atau disebut juga penerjemahan lurus (linear translation) berada di antara penerjemahan kata-demi-kata dan penerjemahan bebas (free translation). Dalam proses penerjemahannya, penerjamah mencari konstruksi gramatikal Bsu yang sepadan atau dekat dengan Bsa. Penerjemahan harfiah ini terlepas dari konteks. Penerjemahan ini mula-mula dilakukan seperti penerjemahan kata-demi-kata, tetapi penerjemah kemudian menyesuaikan susunan kata-katanya sesuai dengan gramatikal Bsa (Soemarno, 1983:25; Newmark, 1981:46; Machali, 2000: 51; Nababan, 2003:33; Moentaha, 2006:48).

\section{Penerjemah Setia}

Dalam penerjemahan setia (faithful translation), penerjemah berupaya mereproduksi makna kontekstual dari teks asli dengan tepat dalam batasan struktur gramatikal teks sasaran. Di sini kata-kata yang bermuatan budaya diterjemahkan akan tetapi penyimpangan tata bahasa dan pilihan kata masih tetap ada atau dibiarkan. Penerjemahan ini berpegang teguh pada maksud dan tujuan Tsu, sehingga hasil terjemahan kadang-kadang masih terasa kaku dan seringkali asing (Newmark, 1981:46; Machali, 2000:51).

4. Penerjemahan Semantis

Penerjemahan semantis (semantic translation) lebih luwes daripada penerjemahan setia. Penerjemahan setia lebih kaku dan tidak kompromi dengan kaidah Bsa atau lebih terikat dengan Bsu, sedangkan penerjemahan semantis lebih fleksibel dengan Bsa. Berbeda dengan penerjemahan setia, penerjemahaan semantic harus mempertimbangkan unsur estetika teks Bsu dengan cara mengkompromikanmakna selama masih dalam batas kewajaran (Newmark,1981:46; Machali, 2000:52).

5. Adaptasi (Saduran)

Adaptasi (adaptation) oleh Newmark (1981:46) disebut dengan metode penerjemahan yang paling bebas (the freest form of translation) dan paling dekat dengan Bsa. Istilah "saduran" dapat diterima di sini, asalkan penyadurannya tidak mengorbankan tema, karakter atau alur dalam Tsu. Memang penerjemahan adaptasi ini banyak digunakan untuk menerjemahkan puisi dan drama. Di sini terjadi peralihan budaya Bsa ke Bsu dan teks asli ditulis kembali serta diadaptasikan ke dalam Tsa. Jika seorang penyair menyadur atau mengadaptasi sebuah naskah drama untuk dimainkan, maka ia harus tetap mempertahankan semua karakter dalam naskah asli dan alur cerita juga tetap dipertahankan, namun dialog Tsu sudah disadur dan disesuaikan dengan budaya Bsa.

6. Penerjemahan Bebas 
Penerjemahan bebas (free translation) merupakan penerjemahan yang lebih mengutamakan isi dari pada bentuk teks Bsu. Biasanya metode ini berbentuk parafrase yang lebih panjang daripada bentuk aslinya, dimaksudkan agar isi atau pesan lebih jelas diterima oleh pengguna Bsa. Terjemahannya bersifat bertele-tele dan panjang lebar, bahkan hasil terjemahannya tampak seperti bukan terjemahan (Newmark, 1981:46; Machali, 2003:53).

7. Penerjemahan Idiomatik

Larson (dalam Choliludin, 2006:23) mengatakan bahwa terjemahan idiomatik (idiomatic translation) menggunakan bentuk alamiah dalam teks Bsa-nya, sesuai dengan konstruksi gramatikalnya dan pilihan leksikalnya. Terjemahan yang benar-benar idiomatik tidak tampak seperti hasil terjemahan. Hasil terjemahannya seolah-olah seperti hasil tulisan langsung dari penutur asli. Maka seorang penerjemah yang baik akan mencoba menerjemahkan teks secara idiomatik. Newmark (1988:47) menambahkan bahwa penerjemahan idiomatik mereproduksi pesan dalam teks Bsa dengan ungkapan yang lebih alamiah dan akrab daripada teks Bsu. Choliludin (2006:222--225) memberi beberapa contoh terjemahan idiomatik sebagaiberikut:

8. Penerjemahan Komunikatif

Menurut Newmark (1981:47), penerjemahan komunikatif (communicative translation) berupaya untuk menerjemahkan makna kontekstual dalam teks Bsu, baik aspek kebahasaan maupun aspek isinya, agar dapat diterima dan dimengerti oleh pembaca. Machali (2000:55) menambahkan bahwa metode ini memperhatikan prinsip-prinsip komunikasi, yaitu mimbar pembaca dan tujuan penerjemahan. Contoh dari metode penerjemahan ini adalah penerjemahan kata spine dalam frase thorns spines in old reef sediments. Jika kata tersebut diterjemahkan oleh seorang ahli biologi, maka padanannya adalah spina (istilah teknis Latin), tetapi jika diterjemahkan untuk mimbar pembaca yang lebih umum, maka kata itu diterjemahkan menjadi 'duri'.

Di samping itu Nababan (2003:41) menjelaskan bahwa penerjemahan komunikatif pada dasarnya menekankan pengalihan pesan. Metode ini sangat memperhatikan pembaca atau pendengar Bsa yang tidak mengharapkan adanya kesulitan-kesulitan dan ketidakjelasan dalam teks terjemahan. Metode ini juga sangat memperhatikan keefektifan bahasa terjemahan. Kalimat 'Awas Anjing Galak' dapat diterjemahkan menjadi Beware of the dog! daripada Beware of the vicious dog! Karena bagaimanapun juga kalimat terjemahan ke-1 sudah mengisyaratkan bahwa anjing itu galak (vicious).

\section{METODE PENELITIAN}

Metodologi yang digunakan dalam penelitian ini adalah metode kualitatif deskriptif dengan menggunakan metode analisis isi atau content analyze yang diterapkan dalam delapan tahapan sesuai dengan saran Carley (2002, 35--40) yakni, (1)menetapkan tataran analisis; (2) menetapkan konsep-konsep untuk dikodifikasi; (3) menetapkan apakah pengkodean ditujukan untuk menyatakan keberadaan atau frekuensi konsep; (4) menetapkan cara membedakan konsepkonsep; (5) mengembangkan aturan pengkodean teks; (6) menetapkan apa yang harus dilakukan terhadap informasi atau data yang tidak relevan; (7) menkodifikasi teks; (8) menganalisis hasil. 


\section{PEMBAHASAN}

Penelitian ini bertujuan untuk menganalisishasil terjemahan Metafora pada Mahasiswa Jurusan Sastra Inggris, Fakultas Bahaasa dan Sastra, Universitas Nasional Jakarta dari segi penerjemahannya dan juga kualitas terjemahannya yang bersifat deskriptif kualitatif. Metafora bertumpu pada konsep perbandingan juga pengalihan baik yang secara eksplisit maupun implisit. Berdasakan data yang berhasil peneliti kumpulkan pada saat di Universitas Nasional, terdapat 50 data yang telah peneliti himpun dari kedua kelas yaitu kelas Interctive Grammar III hamya 20 data saja yang memenuhi kriteria untuk dapat dianalisis. Adapun paparannya adalah sebagai berikut.

\section{Data 1}

Dalam penelitian ini, peneliti membandingkan hasil terjemahan antara penerjemah berpengalaman dengan hasil terjemahan mahasiswa di program studi Sastra Inggris. Pada teks bahasa sumber di atas, terdapat dua ungkapan yang mengandung metafora: yang pertama ialah "her world" dan yang kedua ialah "She travelled often but only through the pages of the books". Berdasarkan data di atas, murid-murid menerjemahkan teks bahasa sumber ke dalam teks bahasa sasaran dengan ungkapan yang hampir serupa, tetapi mereka menggunakan pilihan kata yang berbeda. Penerjemah berpengalaman menerjemahkan ungkapan metafora "her world" dengan kata-kata "dunianya”. Kemudian, penerjemah memberikan penjabaran tentang makna dunianya sebagai "dunia pengetahuanya". Mahasiswa 1 menerjemahkan her world dengan kata-kata "dunia gadis tersebut" Mahasiswa 1 mencoba memperjelas subjek dengan cara menggantikan kata ganti “her” menjadi gadis. Karena, di dalam bahasa Indonesia sebagai bahasa sasaran, tidak memiliki sistem gramatikal jenis kelamin. Di mana kata ganti untuk perempuan dan laki-laki sama yaitu dia. Mahasiswa 1 memaknai ungkapan "her world" sebagai "anganangan, mimpi, atau fantasi dari gadis tersebut".

Dalam menerjemahkan teks bahasa sumber ke bahasa sasaran yang mengandung ungkapan metafora, mahasiswa 1 memaknai ungkapan "She travelled often but only through the pages of the books"sebagai gadis yang dimaksud mengenal dunia luar entah itu informasi apapun melalui buku yang pernah ia baca. Mahasiswa 1 memilih kata "berkelana” untuk mengungkapkan aktivitas yang dilakukan oleh gadis tersebut. Sementara itu, penerjemah berpengalam lebih memilih kata "berpergian" untuk mengungkapkan kegiatan yang dilakukan gadis tersebut. Penerjemah berpengalaman, memaknai ungkapan metafora tersebut dengan "dia membaca buku". Dengan demikian terjemahan yang tepat adalah "kegiatan berpergian yang hanya melalui lembaran- lembaran buku bermakna kegiatan membaca."

Mahasiswa 2, 4, dan 5 menerjemahkan kata “her world” sebagai “dunianya”. Berbeda dengan mahasiswa lainya, mahasiswa 3 menerjemahkan dengan kata “dunia dia”. Mahasiswa 3 menambahkan objek sebagai keterangan. Kemudian, ungkapan "She travelled often but only through the pages of the books" memiliki pemilihan kata dalam menterjemahkan teks bahasa sumber. Mahasiswa 2 mengunakan kata berjalan-jalan, mahasiswa 4 dan 5 menggunakan kata yang sama yaitu berpergian. Sejalan dengan mahasiswa 4 dan 5, penerjemah berpengalaman juga menerjemahkan dengan memilih kata berpergian. Ada beberapa makna yang didapat berdasarkan data di atas yang menggambarkanmakna dari ungkapan metafora yang ada. Mahasiswa 2 memaknai ungkapan "she travelledbut only through the pages of the book" sebagai pemikiran tokoh tersebut yang aktif ketika dia membaca buku, sehingga dia tenggelam di dalamnya. Mahasiswa 3 memaknai ungkapan tersebut seolah-olah si tokoh tersebut berpetualang dengan 
melalui buku yang dia baca. Kemudian, mahasiswa 4 menggambarkan bahwa si tokoh tersebut hanya dapat membayangkan dunia lewat cerita. Sementara mahasiswa 5 memaknai ungkapan tersebut sebagai akibat dari kegiatan membaca yang memberikan tokoh dalam cerita banyak pengalaman yang bersifat imajinatif dengan pikiranya.

\section{Data 2}

Di dalam teks bahasa sumber ini, terdapat sebuah ungkapan metafora yaitu "the savage cries of the storm". Dari data di atas, beberapa mahasiswa memiliki hasil terjemahan yang berbeda untuk mengungkapkan makna dari pada ungkapan metafora tersebut. Mahasiswa 1 menggambarkan bahwa "terdapat tangisan liar", mahasiswa 2 menggambarkan terdapat "teriakan liar", mahasiswa 3 menggunakan kata "jeritan” untuk menggambarkan situasi yang terjadi pada ungkapan metafora tersebut. Dari ketiga hasil terjemahan di atas, mahasiswa 3 tidak menjelaskan atau menyebutkan subjek yang melakukan jeritan, sementara mahasiswa 1 dan 2 menyebutkan subjek. Dari hasil terjemahan mahasiswa 1 dan 2, sangat tampak terdapat ungkapan metafora di bahasa sasaran karena ada benda mati yang bertindak seolah-olah melakukan sesuatu.

Kemudian, dari hasil terjemahan yang ada, ketiga mahasiswa di atas memaknai ungkapan metafora yang terdapat pada bahasa sumber dengan makna yang berbeda. Mahasiswa 1 memaknai ungkapan "the savage cries of the storm"' sebagai

"angin badai yang sangat besar", sedangkan mahasiswa 2 memaknai ungkapan tersebut sebagai "suara tangisan yang terdengar sangat sedih", dan mahasiswa 3 memaknai ungkapan metafora yang terdapat pada bahasa sumber sebagai "pikiran yang menjerit".

Mahasiswa 4 masih menggunakan ungkapan yang hampir serupa dengan mahasiswa sebelumnya untuk mendeskripsikan metafora yang terdapat dalam teks bahasa sumber. Mahasiswa 4 menggunakan kata menangis, seolah-olah badai yang terjadi bisa menangis. Sedangkan mahasiswa 5 menterjemahkan ungkapan metafora yang ada sebagai angin badai yang sangat kencang. Dilihat dari hasil terjemahan yang dilakukan oleh mahasiswa 5, peneliti dapat menyimpulkan bahwa mahasiswa 5 ingin mempermudah pembaca dengan tidak menterjemhkan ungkapan metafora yang ada melainkan langsung mengintreprestasikan makna yang ada. Sementara, mahasiswa 4 memaknai ungkapan tersebut secara literal yaitu "badai menangis liar".

Penerjemah berpengalaman menerjemahkan ungkapan metafora yang terdapat pada bahasa sumber ke dalam bahasa sasaran juga dengan menggunakan ungkapan metafora. Penerjemah berpengalaman menerjemahkan ungkapan "the savage cries of the storm" sebagai "tangisan deras sang badai". Dari hasil terjemahan yang ada, peneliti dapat menyimpulkan bahwa penerjemah berusaha untuk menampilkan esensi dari pada karya sastra yang ada, karena teks yang diterjemahkan merupakan penerjemahan sastra. Penerjemah berpengalaman memaknai ungkapan tersebut sebagai "hujan deras". 


\section{Data 3}

Berdasarkan data yang ada, terdapat dua ungkapan metafora di dalam teks bahasa sumber yaitu: "the wings of the Skylark" dan "the battle". Ungkapan metafora yang ada tergolong sulit untuk dimaknai dengan mencari makna dari ungkapan metafora yang ada, sehingga mahasiswa menerjemahkan teks bahasa sumber ke teks bahasa sasaran secara literal. Mahasiswa 1, 2, dan 4 menterjemahkan ungkapan "The wings of the Skylark" sebagai sepasang sayap dari Skylark dan memaknai dengan hal yang sama. Sementara itu mahasiswa 3 dan 5 menerjemahkan ungkapan metafora tersebut sebagai "sepasang sayap dari seekor burung". Mahasiswa 3 menggambarkan seolah-olah ungkapan yang ada ingin mendeskrpsikan tentang "seekor burung yang selalu bernyayi ketika ia mengepakkan sayapnya”. Sedangkan mahasiswa 5 memaknai ungkapan tersebut sebagai "usaha seseorang untuk menggapai mimpinya".

Ungkapan metafora yang selanjutnya ialah “The battle”. Dari data di atas, hampir semua mahasiswa menerjemahkan ungkapan metafora tersebut secara literal, terkecuali mahasiswa 5 yang mennerjemahkan ungkapan metafora tersebut sebagai sebuah perjuangan bukan suatu peperangan. Hal tersebut sama seperti bagaimana mereka memaknai ungkapan metafora yang terdapat pada teks bahasa sumber. Mereka memaknainya sebagai "suatu perang atau perlawanan terhadap sesuatu", sedangkanmahasiswa 5memaknainya sebagai “sebuah usaha".

Selanjutnya, penerjemah berpengalaman juga menerjemahkan teks bahasa sumber ke dalam teks bahasa sasaran dengan menggunakan ungkapan metafora juga. Ungkapan "The wings of the Skylark" memiliki makna layar dari sebuah kapal sedangkan "The battle" memiliki makna perjuangan, perjuangan yang dimaksud adalah "perjuangan menempuh badai". Daridata yang diperoleh dapat disimpulkan bahwa teks bahasa sumber ingin menggambarkan "bagaimana sebuah kapal dengan layarnya yang harus berhenti berkibar akibat pertarungan dengan lautan luas atau perjuangan menempuh badai".

Data 4

Berdasarkan data yang diperoleh peneliti, mahasiswa memiliki beberapa perbedaan ungkapan yang digunakan dalam menerjemahkan ungkapan yang terdapat pada teks bahasa sumber. Ungkapan metafora yang terdapat pada data ini yaitu " $\boldsymbol{A}$ roller coaster that only goes up". Mahasiswa 1 menerjemahkan ungkapan yang ada secara literal yaitu "saya sedang di roller koster yang mana sedang menuju atas". Kemudian mahasiswa satu memaknai ungkapan tersebut sebagai "sebuah perasaan di mana si tokoh dalam cerita sedang sakit seperti roler koster yang sedang menuju dan menatap langit yang kosong”. Selanjutnya, sama seperti mahasiswa sebelumnya mahasiswa 2 juga menerjemahkan ungkapan metafora yang ada secara literal, tetapi berbeda dengan mahasiswa 1, mahasiswa 2 memaknai ungkapan yang ada sebagai "sebuah perasaan bahagia yang tidak terkira".

Kemudian, mahasiswa 3 juga menerjemahkan ungkapan metafora yang ada juga dengan cara yang sama yaitu secara literal. Sama halnya dengan mahasiswa 1, mahasiswa 3 memaknai ungkapan metafora yang ada sebagai sesuatu yang kurang baik, dia memaknainya sebagai “kematian". Karena, roller coster yang hanya berjalan ke atas tanpa kembali ke bawah. Selanjutnya, berbeda dengan mahasiswa sebelumnya, mahasiswa 4 tidak menerjemahkan ungkapan metafora yang ada melainkan langsung memberikan pengertian daripada ungkapan 
yang dimaksud. Dia memaknai ungkapan metafora dari bahasa sumber tersebut sebagai "keadaan yang tak selalu baik tapi kini selalu baik".

Sama seperti kebanyakan mahasiswa sebelumnya, mahasiswa 5 menerjemahkan ungkapan metafora yang ada secara literal. Kemudian, mahasiswa 5 memaknai ungkapan yang ada sebagai suatu pikiran yang positif. Kemudian, penerjemah berpengalaman juga menerjemahkan ungkapan metafora yang terdapat pada teks bahasa sumber secara literal dengan tidak mengganti langsung ungkapan yang ada. Penerjemah berpengalaman memaknai ungkapan metaforal yang ada sebagai "sebuah perasaan atau keadaan yang sangat bersemangat dan antusias. Berdasarkan data yang diperoleh, penulis dapat menyimpulkan bahwa ungkapan " $\boldsymbol{A}$ roller coaster that only goes up" bermakna positif dan memiliki makna perasaan yang sangat senang.

\section{PENUTUP}

\section{Simpulan}

Dalam penelitian ini dilakukan dua tahap dalam pengumpulan data yakni,(1). Tahap pertama, Data referensi. Data diambil dari 14 (empat belas) novel yang menggunakan bahasa Inggris.(2), Tahap kedua, Data survey lapangan. Data yang telah dirampung diolah oleh peneliti dari 14 (empat belas novel (sumber referensi) yang telah diterjemahkan oleh mahasiswa program studi sastra Inggris di Universitas Nasional Jakarta.

Dari kedua tahapan pengumpulan data tersebut penelitian ini akan menghasilkan sebuah karya ilmiah yang berupa penulisan artikel ilmiah dalam bentuk prosiding Afrika yang telah terakreditasi nasional terakreditasi. Selain daripada sebuah artikel ilmiah, penelitian ini juga akan menghasilkan luaran yang sangat bermanfaat untuk menambah media pembelajaran bagi mahasiswa program studi bahasa Inggris dan para praktisi bahasa. Kamus cetak ini terdiri dari 2 (dua) bahasa, dan kemudian akan diunggah di Blog.

\section{Saran}

Berdasarkansimpulan di atas, peneiti memberi saran guna tercapainya penelitian yang lebih mendalam. diantaranya beberapa saranseperti berikut.

1. Pentingnya melakukan penelitian untuk menggali atau mengembangkan bidang ilmu untuk menambah wawasan yang lebih maksimal.

2. Perlunya penggunaan media pembelajaran baik online maupun cetak sebagai fasilitas pembelajaran.

3. Perlunya pemberian akses yang lebih luas kepada para mahasiswa dan para praktisi bahasa.

4. Dosen, senantiasa berupaya meningkatkan potensi dan kualitasnya sesuai pada bidang ilmukeahliannya, khususnya dalam kualitas mengajar. Dosen harus mampu mengaplikasikan bidang ilmunya ke dalam penggunaan media pembelajaran yang merupakan sarana pembelajaran yang aktual.

5. Lembaga, dalam hal ini Universitas atau Fakultas perlu adanya kerjasama yang baik dengan dosen dalam hal penyediaan fasilitas belajar-mengajar di dalam kelas, seperti dalam penyediaan $L C D$ untuk mendukung berjalannya proses belajar dan mengajar berjalan dengan baik. Lembaga juga senantiasa menyediakan fasiitas bagi dosen dan mahasiswa baik berupa materi atau nonmateri untuk menunjang kegiatan penelitianyang bermanfaat dalam pengembangan ilmu pengetahuan dan wawasan. 


\section{DAFTAR PUSTAKA}

Alm-Arvius, Christina. 2003. Figures of Speech. Sweden: Studentliterature.

Bell, Roger T.1993. Translation and Translating: Theory and Practice. Ed 2.London: Longman,

Eugene. A. Nida and Charles R. Taber. 1969, The Theory and Practice of Translation.Leiden: E.J Brill.

Carley, K. 2002. MECA. Pittsburgh, PA: Carrnegie Mellon University.

Classe, Oliver.2000. Encycopedia of Literary Translation into English. Vol.2. London: Fitzroy Dearborn Publishers.

Danesi, Marcel. 2004.Messages, Signs, and Meanings: A Basic Textbook in Semiotic and Communication Theory. Toronto: Canadian Scholar's Press Inc.

Djajasudarma, T.Fatimah. 1993. Metode Linguistik-Rancangan Metode Penelitian dan Kajian. Bandung: Eresco.

H,Belloc. 1931. On Translation. Oxford: Oxford University Press.

J.C Catford. 1965. A Linguistic Theory of Translation. Oxford: Oxford University Press.

Newmark, Peter. 1981. Approach to Translation. Oxford: Pergamon Press, Ltd.

Pinchuck, Isadore. 1977. Scientific and Technical Translation. London: Andre Deutsch.

Savory, Theodore. 1969. The Art of Translation. London : Jonathan Cape.

Venuti, Lawrence. 1991. Translation Invisibility. 